\title{
衝撃静水圧力を受けるクロスプライ積層円筒殻の動的安定解析
}

\author{
粕 谷 平 和* 山岸 保 司**
}

\section{An Analysis of Dynamic Stability of Cross-Ply Laminated Cylindrical Shells under Impact Hydrostatic Pressure}

by

\author{
Hirakazu Kasuya* and Yasuji YamaGishi **
}

\begin{abstract}
This paper deals with the problem of dynamic stability of cross-ply laminated cylindrical shells under impact hydrostatic pressure is described. First of all, the motion of cylindrical shells under impact hydrostatic pressure is defined as axially symmetric motion. Following this definition, certain perturbations are superimposed on this motion and their effect on the behavior of the shell is investigated. The symmetric state of motion of the shell is called stable if the perturbations remained bounded. The solutions for the prebuckling motion and the perturbed motion are obtained using the Galerkin's method. Stable regions are determined by utilizing Mathieu's equation. The inevitability of dynamically unstable behavior is proved analytically and the effects of various factors, such as hydrostatic pressure ratio, number of layers, stacking sequences and dynamic unstable mode, are clarified.
\end{abstract}

Key words : Structural analysis, Composite materials, Dynamic stability, Cross-ply laminated cylindrical shells, Impact hydrostatic pressure, Mathieu's equation

\section{1 ま え がき}

複合材料を用いて航空宇宙機器のような薄肉構造物を 設計しようとするとき, 構造物に作用する衝撃負荷の存 在を考慮する必要があり, 動的安定問題の力学的な解明 は重要な研究課題である.1) 3)

円筒殻が軸対称荷重を受ける場合，初期運動は軸対称 運動を起こす。著者らは既報において, 座屈前軸詨称運 動を考慮することによって，衝撃継続時間が十分に長い 場合には, 静的座屈值より低い值で動的不安定となる可 能性を示している.) (6)

本論文では，衝撃静水圧力を受けるクロスプライ積層 円筒殻を例に挙げ，既報と同様な手法を用いて動的不安 定現象の必然性を示す。手法としては, 基礎方程式から Mathieu 形方程式を導き, Mathieu の安定判別線図を用 いて, 静的座屈値以下の衝撃静水圧力を負荷させた場合 でも，不安定モードが発生することを明らかにし，不安 定現象に与える諸因子の影響を解析的手法によって検討 する。

\section{2 動的安定解析法}

\section{$2 \cdot 1$ 基礎式}

解析モデルとして Fig. 1 に示すような半径 $R$, 筒長 $L$, 板厚 $h$ のクロスプライ積層円筒殻が衝撃静水圧力 $p(t)$ を受ける場合を考える。座標原点を円筒殼中央にと り，軸方向，円周方向，板厚方向にそれぞれ $x, y, z$ 軸 をとる.また, 積層円筒㲄はFig. 2 に示すように, 各層 とも均質な直交異方性の $N$ 層積層からなり, $k$ 番目の層 は基準面から $z=h_{k} \sim h_{k+1}$ の間に存在し, 繊維は主軸方

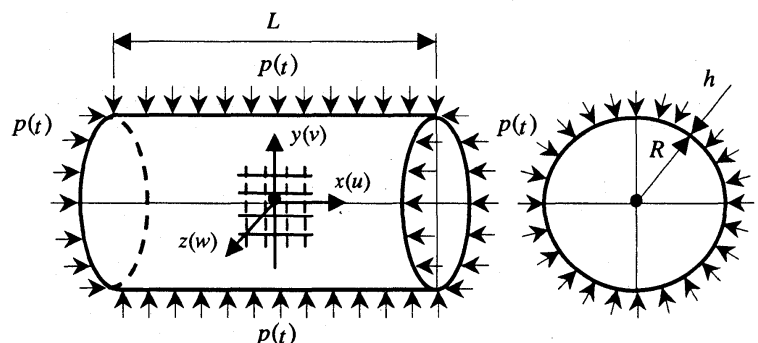

$p(t)$

Fig. 1. Configuration and coordinates of cross-ply laminated cylindrical shell.

向 (0deg.) と円周方向 (90deg.) に交互に向いているもの とする.

有限変形理論を用いた円筒殻の中央面に抢ける面内ひ ずみ成分 $\varepsilon_{x}, \varepsilon_{y}, \gamma_{x y}$, 曲率成分 $\kappa_{x}, \kappa_{y}, \kappa_{x y}$ と変位成分 $u$, $v, w$ との関係は次式のようになる.

$$
\left.\begin{array}{l}
\varepsilon_{x}=\frac{\partial u}{\partial x}+\frac{1}{2}\left(\frac{\partial w}{\partial x}\right)^{2} \\
\varepsilon_{y}=\frac{\partial v}{\partial y}+\frac{1}{2}\left(\frac{\partial w}{\partial y}\right)^{2}+\frac{w}{R} \\
\gamma_{x y}=\frac{\partial u}{\partial y}+\frac{\partial v}{\partial x}+\left(\frac{\partial w}{\partial x}\right)\left(\frac{\partial w}{\partial y}\right) \\
\kappa_{x}=-\frac{\partial^{2} w}{\partial x^{2}}, \kappa_{y}=-\frac{\partial^{2} w}{\partial y^{2}}, \kappa_{x y}=-2 \frac{\partial^{2} w}{\partial x \partial y}
\end{array}\right\}
$$

永井 $\left.{ }^{2)}, 3\right)$ らも指摘しているように, 円筒殻が十分に薄 肉の場合には面内および回転慣性力の影響はいずれも無 視することができる. 本解析モデルの積層円筒殻は十分 に薄肉と考えられるため, 板厚方向すなわち面外慣性力 


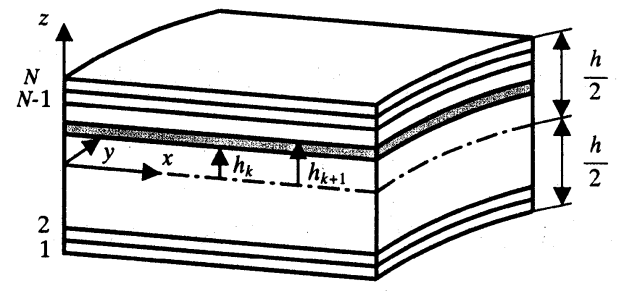

Fig. 2. Geometry of an $N$-layered laminate.

のみ考慮し, ひずみ, 曲率成分と各種剛性項からなる合 応力 $N_{x}, N_{y}, N_{x y}$ および合モーメント $M_{x}, M_{y}, M_{x y}$ を用 いることによって面内および面外の平衡方程式はそれぞ れ次式で表される。

$$
\left.\begin{array}{l}
\frac{\partial N_{x}}{\partial x}+\frac{\partial N_{x y}}{\partial y}=0 \\
\frac{\partial N_{x y}}{\partial x}+\frac{\partial N_{y}}{\partial y}=0 \\
\frac{\partial^{2} M_{x}}{\partial x^{2}}+2 \frac{\partial^{2} M_{x y}}{\partial x \partial y}+\frac{\partial^{2} M_{y}}{\partial y^{2}}-\frac{N_{y}}{R}+N_{x} \frac{\partial^{2} w}{\partial x^{2}} \\
\quad+N_{y} \frac{\partial^{2} w}{\partial y^{2}}+2 N_{x y} \frac{\partial^{2} w}{\partial x \partial y}=p(t)+\rho h \frac{\partial^{2} w}{d t^{2}}
\end{array}\right\}
$$

式 (2) 中の $\rho$ は密度を表す。さらに板厚方向の平衡方 程式は, 応力関数 $F$ と合モーメント成分を用いた次式の ようになる。

$$
\begin{gathered}
D_{11} \frac{\partial^{4} w}{\partial x^{4}}+2\left(D_{12}+2 D_{66}\right) \frac{\partial^{4} w}{\partial x^{2} \partial y^{2}}+D_{22} \frac{\partial^{4} w}{\partial y^{4}}+\frac{h}{R} \frac{\partial^{2} F}{\partial x^{2}} \\
-h \frac{\partial^{2} F}{\partial y^{2}} \frac{\partial^{2} w}{\partial x^{2}}-h \frac{\partial^{2} F}{\partial x^{2}} \frac{\partial^{2} w}{\partial y^{2}}+2 h \frac{\partial^{2} F}{\partial x \partial y} \frac{\partial^{2} w}{\partial x \partial y} \\
+p(t)+\rho h \frac{\partial^{2} w}{\partial t^{2}}=0
\end{gathered}
$$

ここで $D_{i j}$ は曲げ剛性項である。一方，適合条件式は， 次のようになる.

$$
\begin{array}{r}
E_{x} \frac{\partial^{4} F}{\partial x^{4}}-\left(2 v_{x} E_{y}-\frac{E_{x} E_{y}}{G_{x y}}\right) \frac{\partial^{4} F}{\partial x^{2} \partial y^{2}}+E_{y} \frac{\partial^{4} F}{\partial y^{4}} \\
=E_{x} E_{y}\left\{\frac{1}{R} \frac{\partial^{2} w}{\partial x^{2}}+\left(\frac{\partial^{2} w}{\partial x \partial y}\right)^{2}-\frac{\partial^{2} w}{\partial x^{2}} \frac{\partial^{2} w}{\partial y^{2}}\right\}
\end{array}
$$

式 (4) 中の $E_{x}, E_{y}$ は軸方向と円周方向のヤング率, $G_{x y}$ は面内せん断剛性率, $v_{x}, v_{y}$ は軸方向と円周方向に対 するポアソン比である.

境界条件は, 両端 $(x= \pm L / 2)$ において単純支持と仮定 しているため次のように表せる.

$$
w=0, \frac{\partial^{2} w}{\partial x^{2}}=0, \quad N_{x}=0, \quad v=0
$$

\section{$2 \cdot 2$ 負荷条件}

円筒殻に作用する衝撃静水圧力 $p(t)$ の負荷条件を次式 で示す.

$$
\left.\begin{array}{l}
p(t)=\frac{t}{t_{p}} p_{0}, \quad N_{x}(t)=\frac{p(t) R}{2}=\frac{t}{t_{p}} N_{x 0}\left(0 \leqq t \leqq t_{p}\right) \\
p(t)=p_{0}, \quad N_{x}(t)=\frac{p(t) R}{2}=\frac{p_{0} R}{2}=N_{x 0}\left(t_{p} \leqq\right)
\end{array}\right\}
$$

これは, 静水圧力が $t=0$ から作用し, $0 \leqq t \leqq t_{p}$ で 直線的に $p(t)$ が増加し， $t_{p}$ 時間後に一定值 $p_{0}$ に保たれる ことを示している.なお, 衝撃静水圧力の継続時間は無 限と仮定する.

\section{$2 \cdot 3$ 初期運動}

本論文では，円筒殼に作用する静水圧力を軸対称であ ると仮定しているので, 初期に起こる運動は軸対称運動 である。その初期運動に添字 $A$ を付けて表す。

$$
u_{A}=u_{A}(x, t), \quad v_{A}=0, w_{A}=w_{A}(x, t)
$$

さらに初期運動における面外平衡方程式を $H\left(w_{A}\right)$ とおく と次式のようになる。

$$
\begin{gathered}
H\left(w_{A}\right) \equiv D_{11} \frac{\partial^{4} w_{A}}{\partial x^{4}}+N_{x}(t) \frac{\partial^{2} w_{A}}{\partial x^{2}}+E_{y} \frac{w_{A} h}{R^{2}} \\
-v_{y} \frac{N_{x}(t)}{R}+p(t)+\rho h \frac{\partial^{2} w_{A}}{\partial t^{2}}=0
\end{gathered}
$$

式 (8) で示した初期運動の平衡方程式の近似解を求め るにあたり，負荷が作用した場合の波形モード $w_{A}$ を次 式のように仮定する。

$w_{A}=a(t) h\left(1+A_{1} \sin a_{1} x \sinh a_{2} x+A_{2} \cos a_{1} x \cosh a_{2} x\right)$

ここで, $a(t)$ は初期運動の時間に関する未知数であり， 式中の係数は次式のようになる.

$$
\left.\begin{array}{l}
a_{1}=\sqrt{\frac{1}{2 R} \sqrt{\frac{1}{D_{11}}\left(A_{22}-\frac{A_{12}{ }^{2}}{A_{11}}\right)}+\frac{R}{2} \frac{[T]}{4 D_{11}} I} \\
a_{2}=\sqrt{\frac{1}{2 R} \sqrt{\frac{1}{D_{11}}\left(A_{22}-\frac{A_{12}{ }^{2}}{A_{11}}\right)}-\frac{R}{2} \frac{[T]}{4 D_{11}} I}
\end{array}\right\}
$$

ここで $A_{i j}$ は伸張剛性項であり，負荷条件式 (6) で示 した衝撃静水圧力 $p_{0}$ と静的座屈值 $p_{s}$ との比を荷重比 $I$ $\left(=p_{0} / p_{s}\right)$ とする. また, 式 (10) 中の固有べクトル $[T]$ は 静水圧力を受けるクロスプライ積層円筒款の静的座屈応

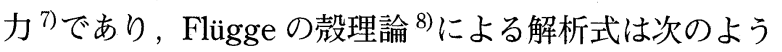
になる。

$\left|\begin{array}{ccc}H_{11}-n^{2} p_{s} R-\lambda^{2} \frac{p_{s} R}{2} & H_{12} & H_{13}+\lambda p_{s} R \\ H_{12} & H_{22}-n^{2} p_{s} R-\lambda^{2} \frac{p_{s} R}{2} & H_{23}-n p_{s} R \\ H_{13}+\lambda p_{s} R & H_{23}-n p_{s} R & H_{33}-n^{2} p_{s} R-\lambda^{2} \frac{p_{s} R}{2}\end{array}\right|=0$

解法は, 上式を係数行列式から一般固有値問題に帰着 させ, 軸方向半波数 $m$, 円周方向波数 $n$ を変化させて得 られる $p_{s}$ の正の最小值が座屈応力であり, $p_{s}=[T]$ で示 される.なお式中の $\lambda(=m \pi R / L)$ は軸方向半波長, $H_{i j}$ $(i, j=1,2,3)$ は形状パラメータ, 各種剛性值からなる項 である.7)また, 式 (9) 中の係数 $A_{1}, A_{2}$ は境界条件によ り異なる值であり, 両端単純支持の本解析においては式 (5) より次のようになる.

$\left.\begin{array}{l}A_{1}=-\frac{2 \alpha_{1} \alpha_{2} \sin \alpha_{1} \sinh \alpha_{2}+\left(\alpha_{1}^{2}-\alpha_{2}^{2}\right) \cos \alpha_{1} \cosh \alpha_{2}}{2 \alpha_{1} \alpha_{2}\left(\cosh ^{2} \alpha_{2}-\sin ^{2} \alpha_{1}\right)} \\ A_{2}=-\frac{2 \alpha_{1} \alpha_{2} \sin \alpha_{1} \sinh \alpha_{2}-\left(\alpha_{1}^{2}-\alpha_{2}^{2}\right) \cos \alpha_{1} \cosh \alpha_{2}}{2 \alpha_{1} \alpha_{2}\left(\cosh ^{2} \alpha_{2}-\sin ^{2} \alpha_{1}\right)}\end{array}\right\}$

ここで, 式中の $\alpha_{1}, \alpha_{2}$ は式 (10) の $a_{1}, a_{2}$ の無次元量 である.4)

そして初期運動のたわみ $w_{A}$ 成分の時間に関する未知 数 $a(t)$ を次の Galerkin 法を用いて求める. 
$\int_{-L / 2}^{L / 2} H\left(w_{A}\right)\left(1+A_{1} \sin a_{1} x \sinh a_{2} x+A_{2} \cos a_{1} x \cosh a_{2} x\right) d x=0$

式 (9) の $w_{A}$ を式 (8) に代入し, 式 (13) の Galerkin 法 を用いることによって $a(t)$ に関する 2 階常微分方程式が 次のように得られる。な拈，各種記号は紙面の都合上省 略する.5)

$\rho h^{2}\left(Y_{0}+A_{1} Y_{1}+A_{2} Y_{2}\right) \frac{d^{2} a(t)}{d t^{2}}+h\left\{\frac{E_{y} h}{R^{2}}\left(Y_{0}+A_{1} Y_{1}+A_{2} Y_{2}\right)\right.$

$\left.+\left(\frac{2}{L}\right)^{2} N_{s}(t)\left(B_{1} Y_{1}+B_{2} Y_{2}\right)+\left(\frac{2}{L}\right)^{4} D_{11}\left(C_{1} Y_{1}+C_{2} Y_{2}\right)\right\} a(t)$

$+\left\{-\frac{v_{y}}{R} N_{x}(t)+\rho(t)\right\} Y_{0}=0$

また, 時間 $t, t_{p}$ を次のように無次元化する.

$$
\tau=\frac{t}{R} \sqrt{\frac{E_{y}}{\rho}}, \quad \tau_{p}=\frac{t_{p}}{R} \sqrt{\frac{E_{y}}{\rho}}
$$

そして, 式 (6) と式 (13) を用いることによって次式が 得られる。

$$
\begin{array}{ll}
\frac{d^{2} a(\tau)}{d \tau^{2}}+\left(q+r \frac{\tau}{\tau_{p}}\right) a(\tau)+s \frac{\tau}{\tau_{p}}=0 & \left(0 \leqq \tau \leqq \tau_{p}\right) \\
\frac{d^{2} a(\tau)}{d \tau^{2}}+(q+r) a(\tau)+s=0 & \left(\tau_{p} \leqq \tau\right)
\end{array}
$$

ここで, 式中の $q, r, s$ は各種衝撃負荷形態時の解析 式 ${ }^{5)} よ り$ 求められ, 衝撃静水圧力負荷の場合には, 簡略 化された次式となる.

$$
\left.\begin{array}{l}
q=1+\frac{D_{11}}{h} \frac{R^{2}}{E_{y}}\left(\frac{2}{L}\right)^{4} \frac{C_{1} Y_{1}+C_{2} Y_{2}}{Y_{0}+A_{1} Y_{1}+A_{2} Y_{2}} \\
r=\frac{4[T]}{E_{y} h} \frac{R}{2}\left(\frac{R}{L}\right)^{2} \frac{B_{1} Y_{1}+B_{2} Y_{2}}{Y_{0}+A_{1} Y_{1}+A_{2} Y_{2}} I \\
s=\left\{-\frac{v_{x}}{E_{x}} \frac{[T]}{2}\left(\frac{R}{h}\right)^{2}+\frac{[T]}{E_{y}}\left(\frac{R}{h}\right)^{2}\right\} \frac{Y_{0}}{Y_{0}+A_{1} Y_{1}+A_{2} Y_{2}} I
\end{array}\right\}
$$

式 (17) の係数 $r$ は衝撃外圧力時には 0 となる項で ある.5),6)なお, 未知数 $a(\tau)$ の初期条件は， $\tau=0$ で次式と なる。

$$
a(\tau)=0, \quad \frac{d a(\tau)}{d \tau}=0
$$

これにより, 初期条件式 (18) のもとで式 (16) を解くこと によって $a(\tau)$ を求めることができる.

\section{$2 \cdot 4$ 擾乱に関する方程式}

初期運動に関する安定, 不安定を議論するために, 微 小擾乱変位 $u_{B}, v_{B}, w_{B}$ を初期運動に加え, その後の応答 を調べる. 境界条件式 (5) を満足する変形様式として, 微小擾乱変位と擾乱時の応力関数を次式のように仮定 する.

$$
\left.\begin{array}{l}
u_{B}=U_{B}(x, t) \sin \frac{n y}{R}, \quad v_{B}=V_{B}(x, t) \cos \frac{n y}{R} \\
w_{B}=b(t) h \cos \frac{m \pi x}{L} \sin \frac{n y}{R}, \quad F_{B}=f_{B}(x, t) \sin \frac{n y}{R}
\end{array}\right\}
$$

ここで, $m$ は軸方向半波数, $n$ は円周方向波数を表し (ただし， $m:$ odd, $n:$ integer)， $b(t)$ は擾乱成分の時間 に関する未知数である. 初期運動の安定, 不安定を議論
するために，初期運動に微小擾乱を与え，その時間に対 する変化を調べる。そこで, 微小擾乱成分に関する平衡 方程式および適合条件式を次のように示す。ここで， $u_{B}$, $v_{B}, w_{B}$ は $x, y, t$ の関数である.

$$
\begin{gathered}
I\left(w_{B}\right) \equiv D_{11} \frac{\partial^{4} w_{B}}{\partial x^{4}}+2\left(D_{12}+2 D_{66}\right) \frac{\partial^{4} w_{B}}{\partial x^{2} \partial y^{2}}+D_{22} \frac{\partial^{4} w_{B}}{\partial y^{4}} \\
+N_{x}(t) \frac{\partial^{2} w_{B}}{\partial x^{2}}+h\left\{v_{y} \frac{N_{x}(t)}{h}-E_{y} \frac{w_{A}}{R}\right\} \frac{\partial^{2} w_{B}}{\partial y^{2}} \\
+\frac{h}{R} \frac{\partial^{2} F_{B}}{\partial x^{2}}-h \frac{\partial^{2} w_{A}}{\partial x^{2}} \frac{\partial^{2} F_{B}}{\partial y^{2}}+\rho h \frac{\partial^{2} w_{B}}{\partial t^{2}}=0 \\
E_{x} \frac{\partial^{4} F_{B}}{\partial x^{4}}-\left(2 v_{x} E_{y}-\frac{E_{x} E_{y}}{G_{x y}}\right) \frac{\partial^{4} F_{B}}{\partial x^{2} \partial y^{2}}+E_{y} \frac{\partial^{4} F_{B}}{\partial y^{4}} \\
=E_{x} E_{y}\left\{\frac{1}{R} \frac{\partial^{2} w_{B}}{\partial x^{2}}-\frac{\partial^{2} w_{A}}{\partial x^{2}} \frac{\partial^{2} w_{B}}{\partial y^{2}}\right\}
\end{gathered}
$$

以上の式を満たすために, 境界条件式 (5) に次の条件 が付け加えられる。

$$
N_{x B}=0, \quad v_{B}=0, \quad \frac{\partial^{2} F_{B}}{\partial x^{2}}=\frac{\partial^{2} F_{B}}{\partial y^{2}}=0
$$

\section{5 動的安定解析式}

$\tau_{p} \leqq \tau$ における初期運動の安定問題を考える. 適合条 件式 (21) に式 (19) を代入し, 求まった $f_{B}$ を式 (19) の 4 番目の式に代入することで応力関数 $F_{B}$ が次のように 求められる. なお, 式中の各種係数は紙面の都合上省略 する.4)

$F_{B}=\frac{E_{y} L^{2} h}{R} b(t)\left[-\frac{(m \pi)^{2}}{(m \pi)^{4}+k^{2}(L m \pi)^{2}+(\ell L)^{4}} \cos \frac{m \pi x}{L}+a(t) \frac{n^{2}}{4} \frac{h}{R}\right.$ $\times\left\{F_{1} \cosh m_{1} x+F_{2} \cosh m_{2} x+H_{1} \sin \left(a_{1}+\frac{m \pi}{L}\right) x \sinh a_{2} x\right.$ $+H_{2} \sin \left(a_{1}-\frac{m \pi}{L}\right) x \sinh a_{2} x+J_{1} \cos \left(a_{1}+\frac{m \pi}{L}\right) x \cosh a_{2} x$ $\left.\left.+J_{2} \cos \left(a_{1}-\frac{m \pi}{L}\right) x \cosh a_{2} x\right\}\right] \sin \frac{n y}{R}$

式 (20) の平衡方程式に応力関数, 負荷条件のほか, 各諸值を代入して, 擾乱成分の時間に関する未知数 $b(t)$ について導くため, 次のような Galerkin 法を用いる.

$$
\int_{0}^{2 \pi R} \int_{-L / 2}^{L / 2} I\left(w_{B}\right) \cos \frac{m \pi x}{L} \sin \frac{n y}{R} d x d y=0
$$

上式を解くことによって $b(t)$ に関する方程式が得ら れる. ここで, 時間の無次元量 $\zeta(=\Omega \tau+\delta)^{5)}$ を導入す ることによって，

$$
\frac{d^{2} b(\varsigma)}{d \varsigma^{2}}+(\phi+\psi \cos \varsigma) b(\varsigma)=0
$$

となる Mathieu 形方程式 ${ }^{9)}$ が得られる.ここで, Mathieu パラメータ $\phi, \psi$ は次式のようになる.

$$
\left.\begin{array}{l}
\phi=\phi_{1}+\phi_{2} \\
\psi=\frac{1}{\Omega^{2}} K n^{2} \alpha \frac{h}{R} W_{1}
\end{array}\right\}
$$

式 (26) の $\phi_{1}, \phi_{2}$ は荷重比 $I$, 固有べクトル $[T]$ を含む 次式のようになる。ここで, $\phi_{2}$ は衝撃外圧力時には 0 と なる項である.5), 6)

$$
\begin{aligned}
\phi_{1} & =\frac{1}{\Omega^{2}} \frac{h}{R}\left[\left(\frac{R}{L}\right)^{4} \frac{1}{R h^{2}}\right. \\
& \times \frac{D_{11}(m \pi)^{4}+2\left(D_{12}+2 D_{66}\right)(m \pi)^{2}(n L / R)^{2}+D_{22}(n L / R)^{4}}{E_{y}}
\end{aligned}
$$




$$
\begin{gathered}
\left.+\frac{R}{h} \frac{(m \pi)^{4}}{(m \pi)^{4}+k^{2}(L m \pi)^{2}+(l L)^{4}}+K n^{2} W_{1}\right] \\
\phi_{2}=-\frac{1}{\Omega^{2}} \frac{R}{2} \frac{[T]}{E_{y} h}\left(\frac{R}{h}\right)^{2}\left\{(m \pi)^{2}+v_{y}\left(\frac{n L}{R}\right)^{2}\right\} I
\end{gathered}
$$

式 (25) の Mathieu パラメータ $\phi, \psi$ は, 円筒壳の幾 何学的形状, 各種剛性值および荷重条件が定まると軸方 向半波数 $m$, 円周方向波数 $n$ のみの関数となるので, $m$, $n$ を順次変化させ，それに対する安定判別を行う。なお， 式 (26) および (27) の $\Omega, K, \alpha$ は式 (9) 中の未知数 $a(t)$ を求める際, Galerkin 法によって得られる定数項であり, $W_{1}$ は各種剛性項, 形状パラメータなどからなる項である が, 紙面の都合上省略する. ${ }^{5)}$ Mathieu 形方程式の解は, $b(\zeta)=0$ という安定解と, $b(\xi)$ が発散振動となる不安 定解が得られる場合があり, それは Mathieu パラメータ $\phi, \psi$ の值に依存する。 $\phi-\psi$ 平面上で安定, 不安定領域 を示すには，その境界線を示す必要があり，それは方程 式の性質上 $2 \pi$ または $4 \pi$ の周期解となる.9 ${ }^{9}$ それらの周期 解を示すことによって得られる Mathieu の安定判別線図 を Fig. 3 に示す. 白い領域が安定領域, 色付きの部分が 不安定領域であり，すべての波形モードが安定領域に存 在した場合，その円筒殼は構造的に安定であると言える.

\section{3 数值計算例と動的安定判別}

数值計算例において用いた弾性定数は, 繊維容積含有 率 $V_{f}=60 \%$ の炭素繊維強化プラスチック材を想定してお り，平均化近似解法による式によって計算された次の值 を用いる.10)

$$
\begin{aligned}
& E_{L}=137\left(G P_{\mathrm{a}}\right), \quad E_{T}=8.17\left(G P_{\mathrm{a}}\right) \\
& G_{L T}=4.75\left(G P_{\mathrm{a}}\right), \quad v_{L}=0.316, \quad v_{T}=0.0189 \\
& \rho=1540\left(\mathrm{~kg} / \mathrm{m}^{3}\right)
\end{aligned}
$$

座屈静水圧力より低い静水圧力が動的に作用する場 合, Mathieuの安定判別線図における円周方向波数 $n$ は 放物線状に存在し， $n$ の増大に伴い Mathieu パラメータ $\phi$, $\psi$ の值も大きくなるが，ほとんどの波形モードが安定領 域に含まれる。そこで, 構造不安定領域の存在に主眼を 置き, 動的不安定モードについて議論するため, Mathieu の安定判別線図において主不安定領域と呼ばれ，もっと も広く重要である Fig. 3 の a 近傍について検討する。

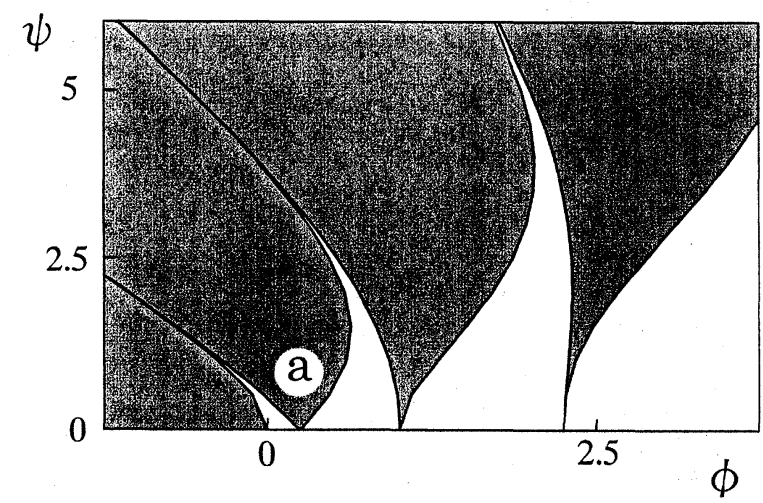

Fig. 3. Mathieu's stability diagram.
著者らが以前に報告した静的負荷を受けるクロスプラ イ積層円筒噎の無次元静水圧座屈值 $K_{h}\left(=p_{s} R / E_{T} h\right)$ を, 最内層積層角を 0 (deg.) とした場合を Fig. 4 に，最内層 積層角を 90 (deg.) とした場合を Fig. 5 にそれぞれ示す?) 最内層積層角 $\theta=0$ (deg.) の場合には，積層数の減少に よる $K_{h}$ 值の低下が顕著に現れ， $Z$ の増加とともにその差 は大きくなっている。また，一般的な筒長を有する積層 円筒殻で, 最内層積層角 $\theta=90$ (deg.)の場合には積層数 の減少に伴い $K_{h}$ 值は増加する。最内層積層角を $\theta=0$ (deg.) とした場合と $\theta=90$ (deg.) とした場合では, 積層数 の多少が $K_{h}$ 值に及ぼす影響は逆で両者の差が明確にな り，積層順序が座屈值に及ぼす影響は顕著になってくる． また, クロスプライ積層円筒殻では, 軸方向半波数 $m$ は, すべての積層数 $N$, 最内層積層角の違いによらず，一定 値 1 であることを示している，そこで上記の内容を考慮 し，動的に静水圧力が作用した場合においても不安定と なる軸方向半波数 $m$ は 1 で励起すると考えられるため, 動的解析時においても $m=1$ とする.

安定判別の一例として, Mathieu パラメータ $\phi, \psi$ の 関係について, 形状パラメータ $R / h=100, Z=900$, 荷

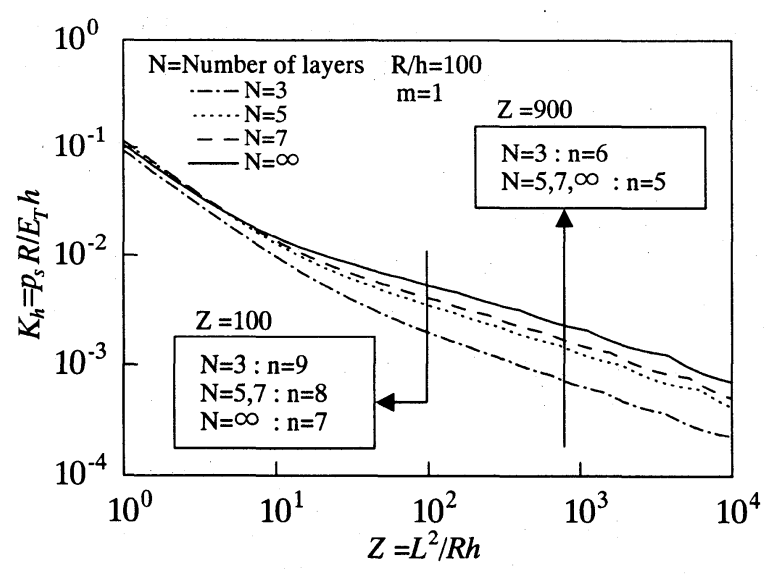

Fig. 4. Variation of buckling coefficients of cross-ply laminated cylindrical shells with shape parameter $Z$. [Inner lamination angle $\theta=0$ (deg.)]

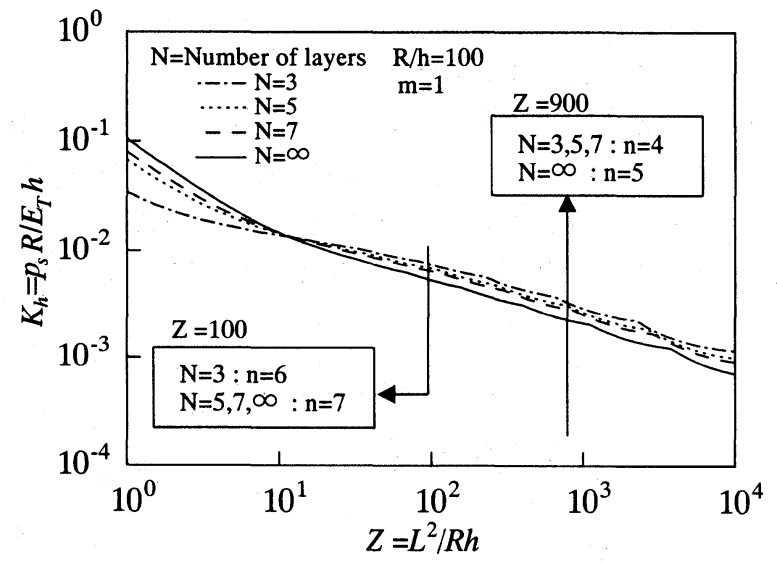

Fig. 5. Variation of buckling coefficients of cross-ply laminated cylindrical shells with shape parameter $Z$. [Inner lamination angle $\dot{\theta}=90$ (deg.)] 


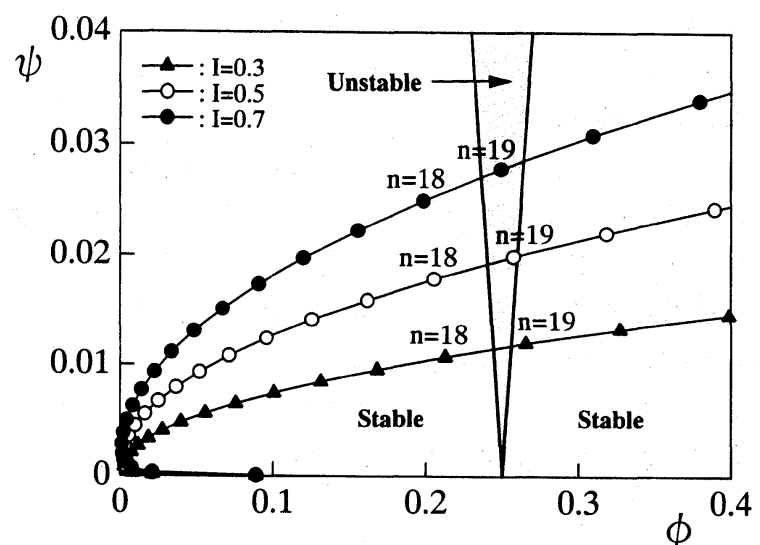

(a) Number of layers $N=3$

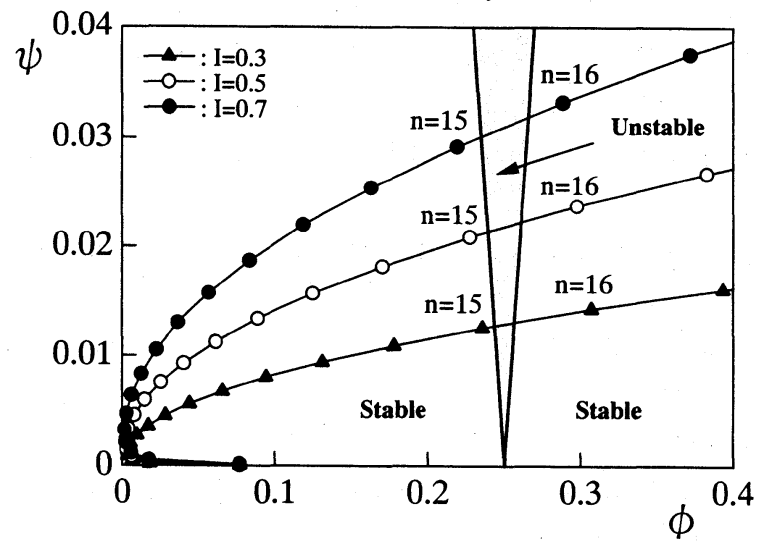

(b) Number of layers $N=5$

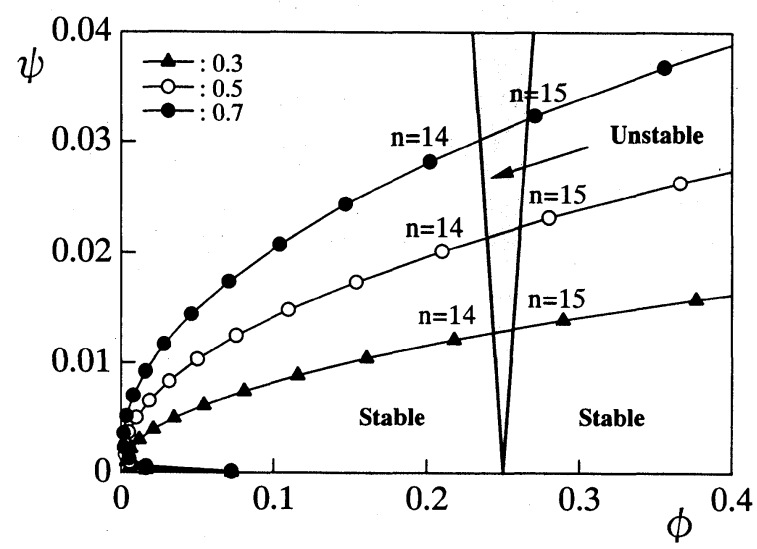

(c) Number of layers $N=7$

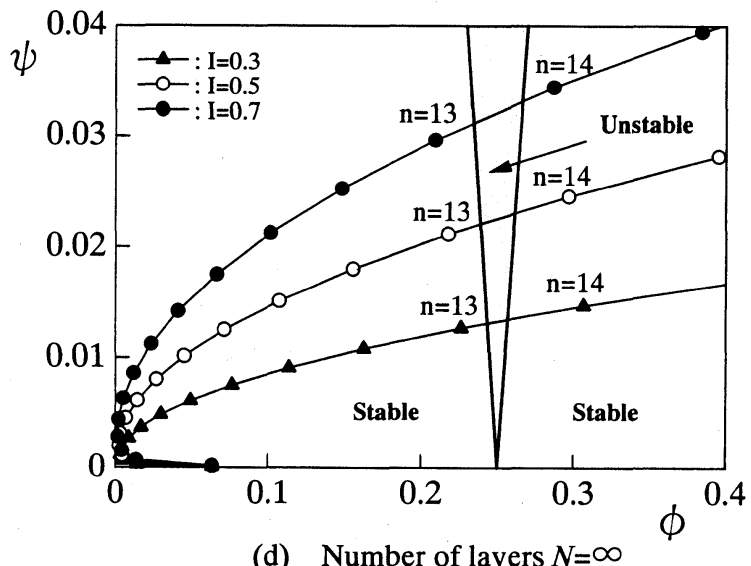

Fig. 6 . The relation between unstable region and wave mode $n$.

[Inner lamination angle $\theta=0$ (deg.)]

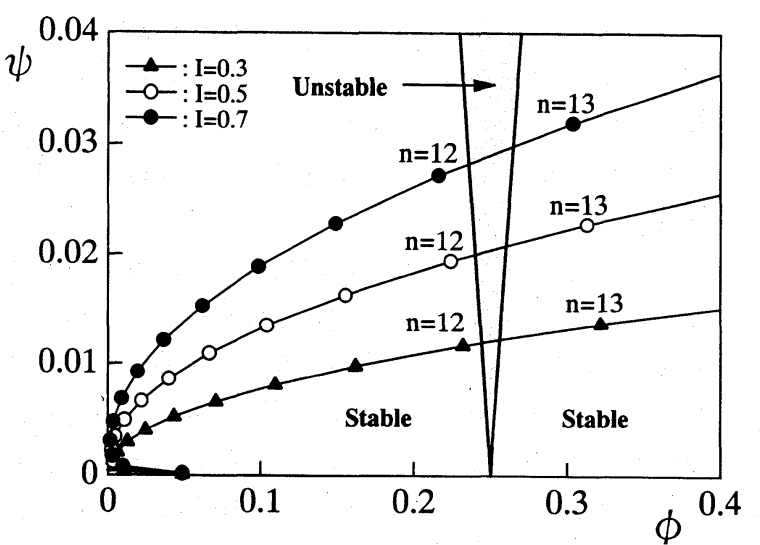

(a) Number of layers $N=3$

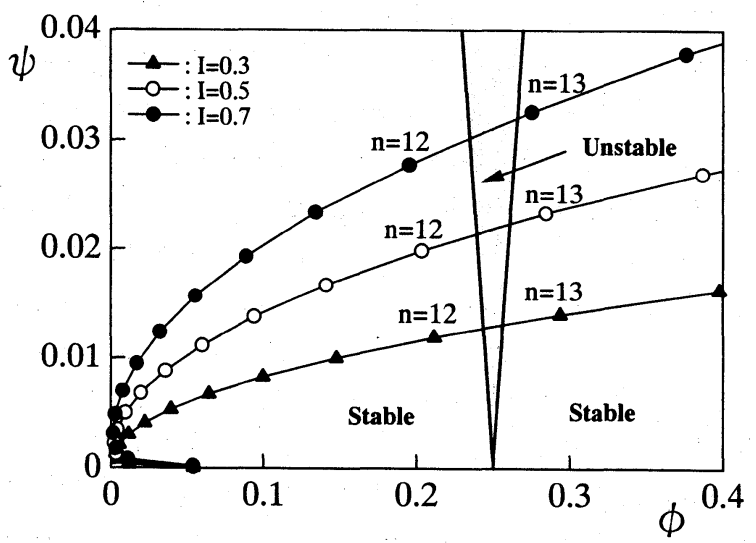

(b) Number of layers $N=5$

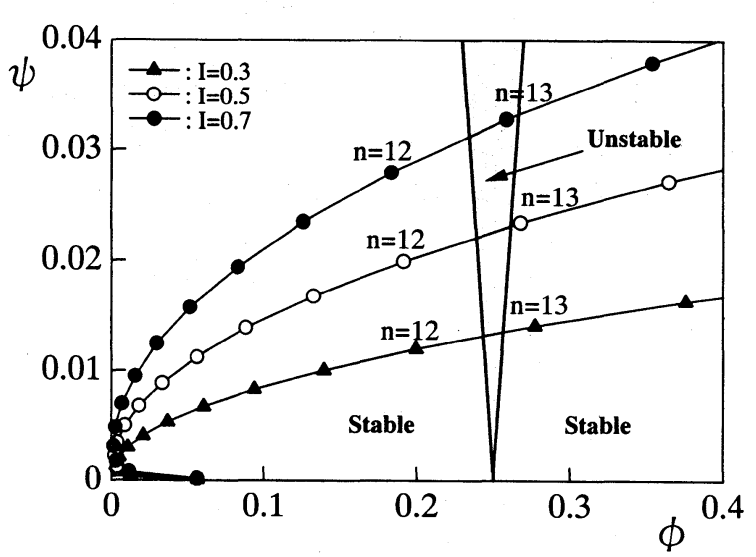

(c) Number of layers $N=7$

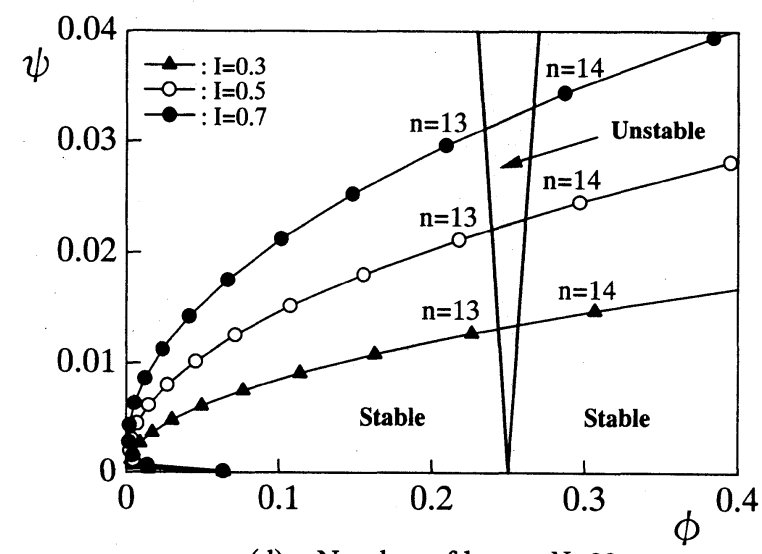

(d) Number of layers $N=\infty$

Fig. 7. The relation between unstable region and wave mode $n$.

[Inner lamination angle $\theta=90$ (deg.)] 
重比 $I$ が $0.3 ， 0.5 ， 0.7$ のクロスプライ積層円筒壳につい て, 最内層積層角 $\theta$ を 0 (deg.) , 90 (deg.)の両方に打い て，積層数 $N$ を $3 ， 5 ， 7 ， \infty$ 層と変化させた場合をそれ ぞれ (a)，(b)，(c)，(d)とし，Fig. 6 およびFig.7にとれ ぞれ示す。

Fig. 6 抢よび Fig. 7 に示すように，積層数 $N$ が増加す るにしたがって，板厚方向に均質となる直交異方性に近 ゔき, $N=\infty て ゙ は$ 最内層積層角の違いによる波形モード の差異はなくなる，そして，最内層積層角 $\theta=0$ (deg.) では積層数の増加に伴い, 円周方向波数 $n$ は低次の波形 モードへと遷移しているのに対し, 最内層積層角 $\theta=90$ (deg.) では積層数の増加に伴い, 若干ではあるが $n$ は高 次の波形モードへの遷移が確認できる．これは円周方向 剛性値と深く関係している.クロスプライ積層円筒殼の 円周方向剛性値は, 最内層積層角 $\theta=90$ (deg.)の積層 数 $N=3$ の場合が一番高く, 直交異方性に近づくに従い 低くなり，最内層積層角 $\theta=0$ (deg.) の積層数 $N=3$ の場 合が一番低い。このことからも，円周方向剛性値の高い 積層構成のほうが波数 $n$ を拘束するため, このような結 果になったと考察される。 また，動的不安定となる場合 の $n$ は, 静的座屈時の波数 (Fig. 4, 5) と比較すると, 非常に大きな值となっている。?そてて高次の波形モード への遷移によって $\psi$ 值は増大するが，荷重比 I を増加さ せることによってその差は顕著になる。 また，本解析に おける負荷形態に打いては, 主不安定領域の増減は見ら れなかった。

なお，動的不安定の起こる最小荷重比の限界を議論す るためには構造減衰を含んだ場合の安定判別式によって 不安定領域を考慮しなければならない。

\section{4 あ と がき}

本論文は, クロスプライ積層口筒殼に衝撃静水圧力を 作用させた場合の動的応答を，構造の安定性という観点 から検討した．静的座屈応力を Flügge の殻理論より解 析し，基礎式には有限変形理論を用い，Mathieu形方程 式を導き, 安定判別線図より安定判別を実施した。そし て, 座屈前軸対称運動と微小擾乱運動を考慮することで, 構造不安定領域を積層構成の影響とともに示し，静的座 屈值と比較して低い衝撃静水圧力を受けた場合において も構造不安定となる可能性を示した。

\section{参 考 文 献}

1) J. C. Yao, AIAA J., 1, 1391 (1963).

2) 永井健一，八巻 昇，日本機械学会論文集，A-45，791 (1979).

3) 永井健一, 八巻 昇, 日本機械学会論文集, C-53，1309 (1987).

4）粕谷平和，根本圭一，日本機械学会論文集，A-59，454 (1993).

5) 粕谷平和, 松岡一雄, 日本機械学会論文集, A-65, 1908 (1999).

6) 粕谷平和, 松岡一雄, 材料, 48, 1367 (1999).

7 ) 山岸保司, 佐藤孝行, 粕谷平和, 東海大学紀要工学部, 41, 129 (2001).

8) W. Flügge, "Stresses in Shells", Chap.7 (1962) SpringerVerlag, Berlin.

9) N. W. McLachan, "Theory and Application of Mathieu Function", Chap.3 (1947) Oxford University Press, New York.

10）植村益次，山田直樹，材料， 24，156（1975）. 